\title{
Viisakusvormidest eesti- ja venekeelsetes ametlikes paralleeltekstides
}

\author{
JELENA VELMAN-OMELINA, \\ VALENTINAŠTŠADNEVA \\ Tartu Ülikool
}

Ülevaade. Artiklis vaadeldakse eesti ja vene etiketile omaseid pöördumisvormeleid kirjalikus tekstis. Tähelepanu keskmes on pöördumised võõra isiku poole, kes on huvitatud sotsiaalselt olulise informatsiooni saamisest. Keelematerjaliks on erinevate žanrite kirjalikud paralleeltekstid. Kaasaegseid paberkandjal avaldatud eestikeelseid ametlikke tekste kõrvutatakse nende venekeelsete versioonidega selleks, et välja selgitada viisakusprintsiibi realiseerimise erinevused ja sarnasused originaaltekstis ning tõlkes.

Võtmesõnad: pöördumisvormid; verbaalviisakus; ametlik tõlketekst; paralleeltekstid; eesti keel; vene keel

\section{Sissejuhatus}

Kodanike ja asutuste/organisatsioonide (riiklike ja mitteriiklike), klientide ja personali, ettevõtte töötajate vahelised sotsiaalsed suhted, nagu ka inimeste vastastikused suhted igapäevaelus, on reguleeritud eetikaga (Blackburn 2001), kõlblusnormide kogumiga. Normid korrastavad suhtlusprotsessis erinevaid ametlikke ja igapäevaseid inimestevahelisi suhteid ning sisaldavad: 1) selliseid indiviidide mittekonfliktse käitumise reegleid, mis reglementeerivad inimeste tegude, žestide, miimika 
olemust, ja 2) verbaalset suhtlust (keeleetiketti) (Formanovskaja 2006). Viimane kujutab endast stilistiliselt markeeritud keeleliste vahendite mikrosüsteemi, mis on samuti ette nähtud konfliktivaba suhtluse saavutamiseks, st keelelise viisakuse realiseerimiseks.

Viisakust on uuritud erinevate humanitaarteaduste raames: kultuuridevahelises kommunikatsioonis, sotsiolingvistikas, psühholingvistikas, psühholoogias, rakenduslingvistikas, pragmaatikas (Lin 2013: 151). Viisakusteooriat hakati aktiivselt arendama pärast Browni ja Levinsoni (1978) artikli ilmumist, mille aluseks oli Goffmani (1967) pakutud mõiste nägu 'face' ning selle säilitamine suhtluses. Tänapäevani ei ole leitud üldtunnustatud määratlust terminile viisakus, uurijad pakuvad välja erinevaid lähenemisi selle mõiste olemusele. Lisaks juba mainitud kontseptsioonile viisakus kui näo säilitamine (Goffman 1967; 1972; Brown \& Levinson 1978), võib arenevatest suundadest nimetada veel järgmisi: viisakus kui kõne maksiimide, reeglite kogum (Lakoff 1973); viisakus kui eetiline kategooria (Formanovskaja 1967; Risinzon 2010); ning hulk teisi lähenemisi (Vlasjan 2011: 36). Siiski on 20. sajandi humanitaarteadused jõudnud mõistmiseni, et viisakus on selline verbaalne ja mitteverbaalne käitumine, mis on suunatud suhtluse meeldiva tonaalsuse loomisele, mis soodustab vastastikkust mõistmist ja konfliktide vältimist (Vlasjan 2011: 38). Seega võib viisakust määratleda kui sotsiaalse koostöö printsiipi, mille aluseks on austus partneri isiku vastu. H. P. Grice väidab, et see üldine põhimõte laieneb nii verbaalsele kui ka mitteverbaalsele inimtegevusele ning aitab saavutada sotsiaalse koostoimimise maksimaalset efektiivsust (Grice 1985: 245).

Meenutagem, et "Browni ja Levinsoni viisakusteooria peab positiivse ja negatiivse näo olemasolu inimkonnale põhimõtteliselt universaalseks, kuigi eri kultuurid peavad oluliseks selle eri aspekte" (Pajusalu 2010: 6). Igas konkreetses kultuuris võib ettekujutus viisakusest ja viisakast käitumisest aja jooksul muutuda, adapteeruda epohhi ja ühiskonnaga; see toimub erinevate sotsiaalsete, kultuuriliste ning ajalooliste tegurite koosmõjul (Svinina 2007: 87). Seetõttu vajabki viisakuse mõiste kasutamine tõlke korrektsuse huvides kindlasti rahvusliku ja ühiskondliku komponendi 
arvestamist. Seejuures tähendab viisakus konfliktide vähendamise viise, reegleid sotsiaalselt otstarbeka ja kohase käitumise jaoks selleks, et luua ja hoida harmoonilisi isikutevahelisi suhteid (Lin 2013: 151).

Verbaalne (keeleline) viisakus realiseerub stilistiliselt markeeritud keelevahendite toel (LES 1990: 413). Samal ajal tähendab viisakus ametlikus suhtluses mitte ainult madalkeelendite või jämedate väljendite puudumist, vaid ka tekstide koostamise stilistilist korrektsust. Kuna ametlikus suhtluses on igal osapoolel ka teatud formaalne (ametlik) staatus (Uzerina 2004: 7), ei ole oluline mitte ainult dokumendi sisu, vaid peab järgima ka teksti-, etiketi- ja keelenorme. Tähelepanu tuleb pöörata asjaolule, et verbaalne viisakus ehk keeleetikett on viisakuse ühe osana tunduvalt kitsam mõiste (Sviridova 2010: 169). Keeleetiketis ilmnevad alati suhtlejate sotsiaalsed positsioonid, kuna keeleetikett ise peegeldab ühiskonna, keele ja kultuuri seoseid ning need seosed väljenduvad paratamatult ka tõlkes.

\section{Eesmärk, materjal ja uurimisobjekt}

Artikli eesmärk on võrrelda etiketi suhtlusvormeleid eesti- ja venekeelsetes paralleelsetes ametlikes tekstides ning välja selgitada, mil määral võetakse neis arvesse viisakusprintsiipi, kuna teksti koostaja pöördub suure hulga adressaatide poole, kes on huvitatud sotsiaalselt olulise informatsiooni saamisest. Loomulikult võib kirjalik ametlik sõnum olla suunatud ka tuttavale, vähetuttavale või kindla staatusega isikule, kuid käesolevas artiklis vaadeldakse eelkõige sellist vahendatud ametlikku suhtlust, mis on suunatud laiale lugejate ringile.

Viisakusvormelite kasutamist eesti-vene keeltepaaris on eesti keeleteadlased juba vaadelnud, kuid suurem osa läbiviidud uurimustest (Keevallik 1998; Pajusalu 2010 jt) põhinevad sotsiolingvistilistest küsitlustest saadud materjalil ning puudutavad peaasjalikult sina/Teie valikut suulises otsesuhtluses, mitte vahendatud pöördumises. Siinses artiklis uuritav keelematerjal pärineb sotsiaalse suunitlusega trükistest ning suulise kõne näiteid kaasatakse analüüsi vaid mõningate võrdluste tarbeks. 
Uurimisobjektiks on erinevate ametkondade, asutuste, firmade voldikud, flaierid jt trükised. Analüüsitakse paberkandjal avaldatud ametlikke informeerivaid, selgitavaid, instrueerivaid ning osaliselt ka reklaamivaid tekste, mida iseloomustab erinev ametlikkuse aste (ametlikkuse astmete kohta vt lähemalt Sologub 2009: 53-55) ning mis täidavad sageli korraga mitut funktsiooni. Admoni järgi teenindavad inimeste praktilisi vajadusi erinevat tüüpi tekstid (Admoni 1994: 103-115). Nendes tekstides edastavad riiklikud ja erainstitutsioonid sotsiaalselt olulist informatsiooni massilisele lugejaskonnale kaitsmaks inimesi erinevate sotsiaalprobleemide eest, samuti ühiskondliku elu parendamiseks. Sellise sotsiaalse suhtluse problemaatika on erinev ning hõlmab õigus-, finants-, tervishoiu-, rahvaspordi-, hariduse-, ökoloogia-, kultuurivaldkonda jms. Taoliste tekstide peamine eesmärk on elanikkonda informeerides selgitada mingisuguste toimingute vajadust, soovitada sobivat käitumisviisi, hoiatada võimalike ebasoovitavate tagajärgede eest jms. Käesolevas uurimuses analüüsiti 119 erineva mahuga ja erineva temaatikaga paralleeltekste kahes keeles; ükskeelset materjali (ainult eesti- või venekeelset) ei ole analüüsis käsitletud. Ühtlasi peab märkima, et mitmetähenduslik termin paralleeltekstid (Grigorjeva 2011: 146) on käesolevas artiklis kasutatud ainult originaal- ja tõlketeksti tähenduses.

Tuleb märkida, et mitte alati ei tõlgita seda tüüpi tekste (näiteks pankades) otse eesti keelest vene keelde, vaid tegemist on hoopis ühe (inglise- või mõne skandinaaviakeelse) algteksti tõlkimisega korraga mitmesse erinevasse keelde. Kõrvutava analüüsi seisukohast on olulised ka sellised sekundaarsed tekstid, kuna originaalteksti tõlkimisel tuleb ideaalis võtta arvesse tervet komplekti tüüpilisi kultuurilis-keelelisi eripärasid sihtkeeles.

Üldiselt väljendub keeleetikett 1) isikuliste asesõnade vormides; 2) asesõnadega arvus ühilduvates tegusõnades; 3) kõnetlussõnades (господин, госпожа - härra, proua); 4) vene keeles võib viisakuskategooria ilmneda isikunime valikus (nii kirjalikus kui ka suulises kõnes), vrd ametlikkuse vähenemist reas: Татьяна Петровна, Татьяна, Таня, Танечка, Танюша, Танька (Tatjana Petrovna, Tatjana, Tanja, Tanečka, 
Tanjuša, Tanka). Analüüsi peamine objekt on isikulised asesõnad, muid viisakuse väljendamiseks tarvitatavaid mooduseid vaadeldakse vaid pelgalt nendega seoses. Selgema ülevaate saamiseks kasutatakse käesolevas artiklis kirjutusviisi $m b \iota(T b)$ / Bbl vene ja sina (Sina) / Teie eesti keele jaoks.

Valikut vormide $m b$ - sina ja $B b l$ - Teie vahel reguleerivad ametlikus suhtluses tavaliselt erinevad reeglid: ametliku kommunikatsiooni ja keeleetiketi normid, konkreetsed nõuded erinevate dokumentide rekvisiitidele, algselt määratletud ametlikkuse (formaalsuse) aste jne. Tõlkimisel ühest keelest teise on oluline võtta arvesse mitte ainult originaalteksti sisu ja vormi eripära, vaid ka tõlkekeele kultuuri- ja keeletraditsioone.

\section{Verbaalne viisakus vene keeles}

Toetudes Browni ja Levinsoni tuntud kontseptsioonile, pakub Rathmayr välja mõisted distantsiviisakus negatiivse viisakuse ja solidaarsusviisakus positiivse viisakuse jaoks. Rathmayr märgib, et vene kultuuris esineb mõlemaid viisakuse tüüpe ning neid kasutatakse kas spontaanselt või sihipäraselt, et saavutada suhtluseesmärke. Ametlikes ja formaalsetes suhetes on olulisem distantsviisakuse strateegia. Erasuhtluses on esimesel kohal solidaarsusviisakus, mis on ka üldiselt vene kultuurile rohkem omane (Rathmayr 2013: 144-147).

Vene keeles tekkis asesõna $B \mathfrak{b l}$ (Teie) viisaka pöördumisena eelkõige saksa keele mõjutusel Peeter I riigisiseses ametlikus kirjavahetuses 17. saj lõpus. Kuigi Peeter I poole pöörduti mõnikord endiselt ka sinatades, kuna keel säilitas kinnistunud isikulises asesõnas vana võrdsete inimeste hõimuühiskonna traditsiooni (Vlast 2007). Seetõttu on venelaste jaoks pöördumisel ühe inimese poole põliseks vormiks mol (sina), nii nagu eestlaste jaokski. Ilmekas näide on 16. saj palvekirja tekst (pöördumine Peeter I poole), kus on kasutatud hulganisti mы-vorme: привез я тебе (tõin ma sinule), твоего царства (sinu tsaaririik), твоего холопа (sinu оri), велел ты (käskisid sina), перед тобой (sinu ееs), бумаги mвоu (sinu käsikirjad) jt (Bolšaja čelobitnaja Ivana Peresvetova). 
Tänapäeva kasutuses täidavad asesõnad $m b l$ ja $B b$ erinevaid funktsioone; sealhulgas ka neid, millel selle artikli raames üksikasjalikult peatuda ei saa. Tervikuna näitab $m b l$-/Bbl-vormide süsteemsus vene keeles ja eriti keeleetiketis seda, et kasutuspraktika on keeles kujundanud ja kinnistanud ametlike (formaalsete) / mitteametlike (mitteformaalsete), vaoshoitud / usalduslike jm suhete sisse- ja ümberlülitamise keerulise mehhanismi (Formanovskaja 1982: 69).

Märkimist väärib asjaolu, et kaasaegses sotsiaalses kontekstis on sina-vormi kasutusvaldkond Euroopa keeltes laienenud. Vene keeles on täheldatud etiketijärgse käitumise seost korporatiivse kultuuriga, näiteks ülikoolide töötajad kasutavad sageli ametliku suhtluse etiketivahendeid; samas eraettevõtete töötajad kasutavad rohkem neid vahendeid, mis on omased argivestlusele (Risinzon 2010: 206). Paljudes asutustes määravad venekeelse suhtlusstiili korporatiivse eetika reeglid. Tegevusvaldkond paneb sageli paika ka töötajate enimeelistatud suhtlusvormi. "Riiklikes struktuurides püsib muutumatuna pöördumine vestluskaaslase poole ees- ja isanimega ning teietades, sest need struktuurid on üles ehitatud väga rangete hierarhiaseaduste järgi. Meediaäris või loomeagentuurides juhtkond ja alluvad reeglina sinatavad üksteist, samasugune suhtumine võib olla ka klientidesse või ajakirjanikesse. Põhjus peitub selles, et need valdkonnad on enamjaolt üles ehitatud isiklikele suhetele ning mida väiksem on inimestevaheline distants, seda edukam on nende koostöö." (Vlast 2007). Samal ajal jääb siiski suhtlemisel klientidega esialgu peamiseks pöördumine viisaka

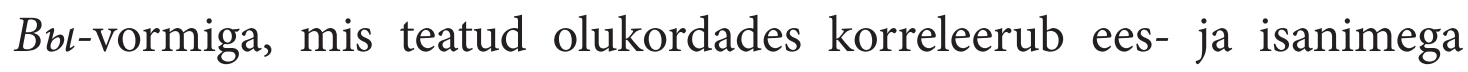
pöördumisega.

Isanime päritolu ja tähenduse küsimust traditsioonilise etiketi seisukohast vaadeldakse põhjalikult Kudrjavcevi (1998: 31-40) artiklis, seetõttu peatume vaid mõningatel iseärasustel, mis ilmnevad isanime kasutamisel koos teiste viisakust väljendavate keelevahenditega kaasaegsetes ametlikes tekstides. Tervikliku venekeelse teksti elemendid on tavaliselt kooskõlas $m b$ - või $B b l$-vormi kasutamisega: etikett nõuab, et rangelt ametlikus pöördumises Господин + фамилия (Härra + perenimi) 
esineb alati $B b l$-vorm. Pöördumine ees- ja isanimega eeldab samuti reeglina $B b$-vormi kasutamist, vähemalt tutvuse algetapil.

Nii suulises kui ka kirjalikus kõnes toob pöördumine vaid eesnimega (ilma isanimeta), kas täieliku passinimega või lühendatud vormiga (Елена, Лена - Elena, Lena) endaga kaasa enamjaolt sinatamise. Samal ajal on intelligentses ametlikus sfääris võimalik samaealiste või nooremate ning samadel hierarhiaastmetel asuvate inimeste poole (pikaaegse tutvuse korral) pöörduda eesnimega (kas passi- või mingisuguse tuletatud vormiga, kuid ilma isanimeta), aga koos Bbl-vormiga: Леночка, Вы подготовили отчет? Прошу выслать его не позднее понедельника (Lеnос̌ka, kas Te tegite aruande valmis? Palun saatke see ära hiljemalt esmaspäeval).

Erilist tähelepanu väärib viimaste aastate nähtus internetikirjavahetuses, mis on siiski harvaesinev paberkandjal: $T b$ kirjutamine suure algustähega. Mitteformaalne ainsuse 2. isiku asesõna kirjutatakse suure algustähega nt saksa, poola ja tšehhi keeles. Vene keeles esines sellist kirjaviisi varem ainult religioossetes või poeetilistes tekstides, nüüd on see tasapisi imbumas ka ametlikku suhtlusesse (Gorickaja 2009), mille üks põhjus on ilmselt tõlgitud paralleeltekstide kasutamine ametlikus valdkonnas. Vormi $T b$ pragmaatiline laeng on tingitud suure algustähe erilisest funktsioonist, mis tõstab sõna esile ja annab tunnistust subjekti olulisusest ning tema positiivsest hinnangust. Seetõttu võib Tbı kirjutamine suure algustähega anda märku viisakusest ja austusest ilma sotsiaalset distantsi demonstreerimata (Gorickaja 2009), samas kui teie kirjutamine väikese algustähega viitab sotsiaalsele distantsile väljendamata pöörduja isiklikku suhtumist adressaati.

Tähelepanuväärne on see, et vene televisioonis ja raadios on juba palju aastaid jäljendatud ameerikalikku maneeri suhelda familiaarsesõbraliku tonaalsusega: tuntud vanemaid inimesi sinatatakse ja nende poole pöördutakse vaid eesnimega. Kõnealusel juhul saab rääkida siiski vaid uuest tendentsist, mis ei ole veel muutunud normiks. Kuid nagu näitab suhtluspraktika, ametlikus (formaalses) olukorras, isegi mitteametliku suulise suhtluse korral, peetakse sobivamaks ikkagi pöördumist ees- ja isanimega ning teietamist. 
Seega tänapäevased muutused ei tähenda ainult näilist lihtsustumist, vaid ka teatud viisil keeleetiketi süsteemi keerukamaks muutumist, sealhulgas ka ametliku suhtlemise valdkonnas. Kuid vaatamata teatud nihkele nii Venemaa kui ka Eesti venelaste ametlikus etiketis, jääb siiski peamiseks viisakaks võõra inimese poole pöördumise vormiks mõlemas vene keele regionaalses variandis ikkagi asesõna $B b \iota$.

\section{Verbaalne viisakus eesti keeles}

Nii nagu vene keeles on ka eesti keeles Teie-vormi (aga ka viisakate pöördumiste härra, proua, mis on laenatud saksa keelest) ilmumine ja levimine seletatav võõrkeele mõjuga. Keevalliku (1998: 542) seisukoht on, et "Eesti puhul võiks kõne alla tulla eelkõige saksa ja vene kultuuri mõju, kusjuures kumbki süsteem ei kattu täpselt eesti omaga”. Kuid keeleetikett, mis kujunes välja möödunud sajanditel ning kinnistus siis, elab nüüd üle muutusi, mis on tingitud ameerika inglise ja Põhjamaade keelte mõjust ning see ilmneb eelkõige kõhklustes õige vormi valimisel. Näiteks Tööinspektsiooni informeerivates tekstides võib kohata lauseid: Ehita targalt!; Helista juristi infotelefonile jms. Kuigi siin puuduvad asesõnad, luuakse ikkagi mulje, et eesti ametliku suhtluse etikett lubab teatud tingimustel kasutada viisakate pöördumistena vorme Sina/sina.

Eesti keele asjatundjad täheldavad normide ebastabiilsust ja variatiivsust kõnealuses valdkonnas, mistõttu tekivad vastuolulised ettekujutused eesti etiketist (Kokšarova \& Vogelberg 2009: 61). Keevallik (1998: 552) on juba 1998. aastal pööranud tähelepanu sellele, et eesti keeles on märgata kõnetussõna teie taandumise tendentsi. Pajusalu viitab oma artiklis ainsuse vormi mittenormatiivsele kasutamisele ning väidab, et "Eesti ühiskonnas on kombeks võõraid täiskasvanuid teietada" (Pajusalu 2010: 5).

Samal ajal läbi viidud uuringute järeldus on, et eesti ja vene keel erineb viisakusvormide kasutamise poolest. Üldiselt on teietamine "venelase jaoks alati austav ja positiivne, samas kui eestlase jaoks võib see olla ka tõrjumise vahend" (Pajusalu jt 2010: 209). Seega on eesti 
keeleteadlased arvamusel, et eestlasest vestluskaaslane ei pruugi alati Teie-vormi positiivselt suhtuda. Seejuures kasutatakse vene keeles teievormi rohkem kui eesti keeles ja see on rohkem seotud vanuselise distantsiga (Pajusalu 2014: 253). Ülaltoodud ülevaatest on näha, et viimane väide vanuse kohta ei võta arvesse kogu olukorda. Näiteks võib vene suulises ja kirjalikus suhtluses mõnikord ette tulla olukord, mil solvunud inimene distantseerub viisaka teietamise abil teadlikult oma solvajast ükskõik kui vanast heast tuttavast.

Seega on valik Sina-/sina- ja Teie-vormi vahel seotud teatud pragmaatikast tingitud raskustega, kuna teksti koostaja peab arvestama nii keeleetiketi reeglitega, mis eeldab Teie-vormi kasutamist pöördumisel võõra isiku poole, kui ka võimalusega luua sõbralikum suhtlusatmosfäär, mis saavutatakse pöördumisega Sina/sina. Samal ajal tasub meenutada, et eestikeelsetes ametlikes tekstides, millel on kindlad adressaadid, kasutatakse endiselt aktiivselt Teie-vormi ja viisakaid kõnetussõnu härra, proua, näiteks Tere Jelena, Tänan Teid pöördumise eest! Palun saatke oma kontaktnumber, et saaksin Teiega telefonitsi ühendust võtta (autori kirjavahetusest).

Tuleb tunnistada, et ametlikus suhtluses on õige pöördumisvormi valik eriti oluline ning seetõttu pole sugugi juhuslik Keevalliku märkus: "Kohustuslik valik kahe vormi vahel on viinud nii kaugele, et neile omistatakse keeleühiskonnas hiigelsuur tähendus. Väikeses asesõnas või tegusõnalõpus võib sisalduda inimese kogu ühiskondlik seisus" (Keevallik 1998: 551). See väide laieneb tegelikult mõlemale (eesti ja vene) keelele, mis säilitavad vaatamata teatud ühistele tendentsidele ikkagi oma eripära ka keeleetiketi valdkonnas.

\section{Eesti- ja venekeelsete paralleeltekstide kõrvutamise tulemused}

Eesti- ja venekeelsete kirjalike paralleeltekstide võrdlemine annab tunnistust sellest, et Eesti tingimustes on ametlike suhete sfääris tegu eelkõige eesti-vene tõlgetega. 
Nii suulises kui ka kirjalikus ametlikus suhtluses kasutatakse vene diasporaas pragmaatilistel põhjustel traditsioonilist viisakat pöördumist ees- ja isanimega harvemini kui Venemaal. Selline pöördumine asendatakse osaliselt täisnime kasutamisega koos asesõnaga Bbl/Teie: Наталья, в случае несогласия с нашим решением Вы имеете право обратиться $\kappa$ ropucmy (Natalja, kui Te ei nõustu meie otsusega, on Teil õigus pöörduda juristi poole). Samal ajal aga on suulises vestluses venekeelsetes haridusasutustes, akadeemilises kogukonnas, üksikutes töökollektiivides enamjaolt säilinud kinnistunud traditsioonilised keeleetiketi normid.

Järgnevalt vaatame, milliseid variante tegelikult kasutatakse paralleeltekstides, millest eestikeelsed tekstid on originaalsed ning venekeelsed tõlked. Keelematerjali analüüsimisel ei võetud arvesse vaid erinevaid asesõnade vorme ning nendega arvus ühilduvaid tegusõnu, vaid ka asesõnade erinevaid kirjutamisviise. Vahemärkusena niipalju, et ametlikes tekstides ei esine $\mathrm{Sa} / \mathrm{sa}$ lühivorme (erinevalt lühivormidest Te/te). Uurimuse tulemus esitatakse tabeli kujul (vt tabel 1), kompaktsuse ja selguse huvides ei ole sellesse tabelisse kaasatud neid juhtumeid, kui viisakat pöördumist dubleeriti üheaegselt asesõna ja tegusõna kasutamisega ühe lause piires (vt allpool näited 8, 9, 12, 13). Kõik ülejäänud võimalikud kirjaliku teksti originaali ja tõlke vastavused on tabelis ära toodud: märgiga "+" tähistatakse neid variante, mis langevad vormi osas kokku, ning märgiga "_" nende puudumist.

TABEL 1. Eestikeelse originaalteksti ja venekeelse tõlketeksti vasted

\begin{tabular}{|l|c|c|c|c|c|c|}
\hline Tõlketekst & Sina & sina & Teie & $\begin{array}{c}\text { Te/te } \\
\text { (lühi- } \\
\text { vormid) }\end{array}$ & $\begin{array}{c}\text { Verbi } \\
\text { ainsuse } \\
\text { vorm }\end{array}$ & $\begin{array}{c}\text { Verbi } \\
\text { mitmuse } \\
\text { vorm }\end{array}$ \\
\hline Вы & + & - & + & + & & \\
\hline ты & - & - & - & & & \\
\hline Ты & + & - & - & & & \\
\hline Verbi ainsuse vorm & & & & & + & - \\
\hline Verbi mitmuse vorm & & & & & + & + \\
\hline
\end{tabular}


Tabelis 1 toodud kombinatsioone illustreeritakse konkreetsete näidetega erinevatest ametlikest kirjalikest tekstidest (oluline on pöörata tähelepanu sellele, et kõik keelenäited on esitatud nende algsel kujul). Kogutud materjali analüüs tõi välja terve rea tüüpilisi vastavusi järgmistes rühmades.

\subsection{Asesõnad}

\subsubsection{Teie - Вы}

Vene keelde tõlgitud tekstides on 3 erinevat võimalust eestikeelse originaali Teie edasiandmiseks. Esimene võimalus on asesõna vormi täpne ekvivalent (1). Teisel juhul, kui eestikeelset viisakat pöördumist väljendatakse vaid verbivormidega (eesti keele seisukohast võib selliseid keelefakte vaadelda kui pöördumist hulga võõraste isikute poole), võib seda vene keeles edasi anda nii ase- kui ka tegusõna üheaegse mitmuse vormide kasutamisega.

(1) Rahavoogude juhtimisel tagab Teile paindlikkuse arvelduslaen. I Расчетный кредит обеспечит Вам гибкость при управлении денежными потоками. (SEB panga voldik)

\subsubsection{Te/te - Вы}

Ametlikes tekstides esinevad ka Te/te lühivormid. Silma torkab eesti keele võimalus kasutada asesõna väikese algustähega (te) ja venekeelse variandi tavapärane suur algustäht $(\mathrm{Bbl})(3)$.

(2) Kui Teie tööandja kasutab E-TVL teenust, ei pea Te võtma arstilt paberlehte. / Если Ваш работодатель пользуется услугой E-TVL, то Вы не должны брать у врача бумажные листы. (Eesti Haigekassa voldik)

(3) Kui võti on kaduma läinud või te pole kindel, et korterit või maja ostes kõik võtmekoopiad enda valdusesse saite, tuleks esimesel võimalusel ukselukud vahetada. / Если ключи потерялись или Вы не уверены, что при покупке квартиры или дома Вы получили в своё владение все 
копии ключей, то при первой возможности необходимо поменять дверные замки. (Seesam Kindlustuse voldik)

\subsubsection{Sina - Ты}

Ametlikes paralleeltekstides esineb pöördumisi Sina-vormis ja Tbl-vormis, mis koos teiste keelevahenditega vähendavad ametlikkuse astet nii eesti kui ka vene keeles. Väikese algustähega kirjutatud asesõnade paari sina - $m$ s analüüsitavas materjalis ei leidunud. Öeldu tähendab, et vormid Sina - Tol on võetud kasutusele selleks, et vähendada suhtlejatevahelist distantsi:

(4) Leiame alati Sinule sobivaima lahenduse. / Mь всегда найдем подходящее для Тебя решение. (Liisi järelmaksu flaier)

Tasub märkida, et ka asesõna Sina ei ole alati vene keelde tõlgitud (vt allpool näide 16).

\subsubsection{Sina - Вы}

Venekeelses tekstis võib eestikeelne Sina olla asendatud vormiga $B b$ :

(5) Kadunud autovõtmete korral viiakse Sind asendusvõtmete järele. / Прu пропаже ключей отвезут Вас за запасными ключами. (ERGO flaier)

\subsection{Verbivormid}

\subsubsection{Verbi ainsuse vorm - verbi mitmuse vorm}

Küllaltki sagedased on juhtumid, kui tõlkesse ilmub tegusõna mitmuse vorm, vaatamata sellele, et originaali tekstis kasutatakse verbi ainsuses:

(6) Vaata lähemalt. Tutvu uue 5-eurose pangatähega. / Присмотрumecb. Знакомьтесь с новой 5-евровой банкнотой. (Euroopa keskpanga infovoldik)

(7) Tule ja mü̈̈ ilma vahendajateta. / Приходите и продавайте без посредников. (ostame.ee flaier) 


\subsubsection{Verbi ainsuse vorm - verbi mitmuse vorm + Вы-vorm}

Venekeelses tõlkes võib viisakat pöördumist võimendada samaaegselt ka isikulise asesõna mitmuse vormi kasutamisega:

(8) Enne tööle asumist lepi tööandjaga kokku, kui palju töö eest tasu saad, kuidas tö̈tasu arvutatakse ja makstakse ning millal on palgapäev. I Перед тем как приступать к работе, договоритесь с работодателем о размере Вашей заработной платы о том, как она будет рассчитываться и выплачиваться, и о том, в какой день Вы будете ее получать. (Sotsiaalministeeriumi brošüür)

(9) Ainult ERGO kaskokindlustusega saad kaasa tasuta üleeuroopalise autoabi. Helista ja oleme juba teel! / Только с каско ERGO Вы получаете общеевропейскую бесплатную автопомощь. Позвони и мы уже в nymu! (ERGO Kindlustuse flaier)

Tähelepanuväärne on asjaolu, et näites (9) on eestikeelne verb saad tõlgitud Вы получаете (kaks mitmusevormi) ning samas on kasutatud täpset vastet eestikeelsele helista - позвони (käskiva teguviisi ainsuse vorm).

\subsubsection{Verbi ainsuse vorm - verbi ainsuse vorm}

Kui eestikeelses tekstis esineb käskiva kõneviisi ainsuse vorm, siis mõnikord säilitatakse tõlkes ka originaali verbivormi ainsus:

(10) Otsusta ja kandideeri! / Прими решение и кандидируй! (Maхima flaier)

\subsubsection{Verbi mitmuse vorm - verbi mitmuse vorm}

Sellistel juhtudel kui eestikeelses tekstis kasutatakse käskiva kõneviisi mitmuse vormi, säilib see reeglina ka tõlketekstis:

(11) Asetage pakk kappi ja sulgege uks. / Поместите посылку в шкаф и закройте двериу. (Itella Smartposti voldik) 


\subsubsection{Verbi mitmuse vorm - verbi mitmuse vorm + Вы-vorm}

Kogutud keelematerjali põhjal võib järeldada, et võrreldes tõlketekstidega esineb algtekstides harvemini verbi mitmuse ja asesõna mitmuse samaaegne kasutamine:

(12) Hoidke alles seda tü̈̈pi vara jäänuseid, mille eest soovite saada hüvitist. / Сохраните остатки того типа имущества, за которое Вы хотите получить возмещение. (Seesam Kindlustuse brošüür)

(13) Kui lahkute kodust, ärge jätke pesumasinat tööle. / Если Вы уходите из дома, не оставляйте стиральную машину включенной. (Seеsam Kindlustuse brošüür)

(14) Laenu taotlemiseks interneti teel täitke taotlusvorm aadressil www.seb.ee ning komplekteerige vajalikud dokumendid, mille loetelu leiate samuti meie kodulehelt. I Для ходатайства о кредите через интернет заполните форму ходатайства на www.seb.eе и подготовьте необходимые документы, перечень которых Вы также найдете на нашем сайте. (SEB panga voldik)

(15) Kui Teil on soov ja huvi töötoas osaleda, andke sellest teada oma konsultandile, kes Teid töötuppa registreerib. / Если у Вас есть желание принять участие в семинаре, сообщие об этом своему консультанту, который Вас зарегистрирует. (Eesti Töötukassa voldik)

\subsection{Tõlkes puudub viisakas pöördumine}

Mõningatel juhtudel loobub tõlkija üldse kasutamast asesõna või isikulist verbivormi viisaka pöördumisena, kuigi nende puudumist ei saa seletada keelesüsteemide või -etiketi erinevustega. Sellistes venekeelsetes tõlgetes edastatakse infomatsioon objektiivses isikuta vormis, st üldse ilma adressaatide poole pöördumiseta (16-17).

(16) Ostu planeerimisel aitab Sind juuresolev kuumaksete näidistabel. I Спланировать покупку поможет данная таблица ежемесячных платежей. (Liisi järelmaksu flaier)

(17) Teiste riikide pädevate asutuste kontaktandmed ning kõik taotluste ja avalduste vormid leiate haigekassa koduleheküljelt. / Контактные 
данные компетентных учреждений других стран Европейского Союза, а также все бланки заявлений и ходатайств помещены на веб-странице Больничной кассы Эстонии. (Eesti Haigekassa voldik)

Niisiis võib ametlikes tõlketekstides näha erinevaid adressaadi poole pöördumise viise: alates sõna-sõnalisest tõlkest kuni objektiivse isikuta vormini. Kusjuures üsna tüüpiliseks (eriti venekeelses tõlketekstis) võib lugeda viisakusvormide dubleerimist ehk verbi mitmuse ja asesõna mitmuse vormi samaaegset kasutamist.

\section{Kokkuvõte}

Kogutud paralleeltekstide (st eestikeelsete originaalide ja venekeelsete tõlketekstide) süstematiseerimine annab tunnistust sellest, et tänapäeva kirjalikes sotsiaalse suunitlusega tekstides esinevad erinevad tõlkeviisid: otsetõlked nagu Sina - Ta ja Teie - Bb ning tõlge Sina - Bbı. Tüüpiline on ka ainsuse vormis oleva eestikeelse tegusõna edasiandmine venekeelse mitmuse vormis tegusõnaga.

Tähelepanekud näitavad, et mida olulisem on informeeriva teksti teema (näiteks tööhõivega, rahvatervisega, finantskohustustega seotud informatsioon jms), mida vastustundlikumalt peab adressaat võtma vastu pöörduja sõnumi, mida autoriteetsem on pöörduja ise, seda rangemalt järgitakse tõlkekeelele omaseid keeleetiketi norme. See ilmneb asjaolus, et tõlkija kasutab üheaegselt mitmuses nii ase- kui ka tegusõna vormi. Neid põhimõtteid on silmas peetud näiteks juriidilistele isikutele mõeldud SEB panga (näide 14), töötukassa (15), sotsiaalministeeriumi (8) jt infovoldikute tõlgetes.

Analüüsitud materjal lubab järeldada, et mõlemad kõrvutatavad keeled on mõjutatud uutest suundadest ning seetõttu varieerub keeleetiketi vahendite, eriti vormide sina - mbl ja Teie - Bbl kasutamine mõlema keele praktikas. Seejuures peegeldab keeleetikett jätkuvalt suhtluse osapoolte sotsiaalseid positsioone nii eesti kui ka vene keeles. Valik sina - mbl või Teie - Bbı on seotud erinevate tunnustega, milleks on: a) kommunikatiivne olukord (ametlik või mitteametlik, avalik või 
mitteavalik suhtlus jms); b) suhtluse osapooled (vanus, sotsiaalne staatus jms); c) suhted osapoolte vahel (nende tutvuse aste, soov rõhutada / mitte rõhutada nendevahelist distantsi jms).

$B b$ - või $m b l$-vormi / Teie-või sina-vormi asjatundlik valik ja oskuslik kasutamine pöördumisel loob sobiva ja meeldiva suhtluse mikrokliima. Seetõttu tuleb kultuuridevahelises ametlikus kommunikatsioonis, mis peegeldub ametlike tekstide originaalides ja tõlgetes, arvesse võtta mitte ainult keele-, vaid ka kultuuritraditsioone.

\section{Kirjandus}

Admoni 1994 = В. Г. Адмони. Система форм речевого высказывания ['The system of verbal expression forms']. Санкт-Петербург: Наука, 103-115.

Blackburn, Simon 2001. Being Good: A Short Introduction to Ethics. Oxford: Oxford University Press.

Bolšaja čelobitnaja Ivana Peresvetova $=$ Большая челобитная Ивана Пересветова 1540-е гг. ['Ivan Peresvetov great petition 1540's']. Сочинения Ивана Семеновича Пересветова. Библиотека литературы Древней Руси / РАН. ИРЛИ. Т 9: Конец XIV - первая половина XVI века. Санкт-Петербург: Наука, 2000. http://lib.pushkinskijdom.ru/Default. aspx?tabid=5115 (15.9.2015).

Brown, Penelope, Stephen Levinson 1978. Universals in language usage: Politeness phenomena. - Esther N. Goody (Ed.), Questions and Politeness: Strategies in Social Interaction. Cambridge: Cambridge University Press, 56-311.

Formanovskaja 1982 = Н. И. Формановская. Русский речевой этикет: лингвистический и методический аспекты ['Russian speech etiquette: linguistic and methodical aspects']. Москва: Русский язык.

Goffman, Erving 1967. Interactional Ritual: Essay on Face-to-Face Behaviour. Garden City, New York: Anchor Books.

Goffman, Erving 1972. On Face-Work: An Analysis of Ritual Elements in Social Interaction. - John Laver, Sandy Hutcheson (Eds.), Communication in Face-to-Face Interaction. Harmondsworth: Penguin, 319-346.

Gorickaja 2009 = О. С. Горицкая. Обращение на ты и Вы в русской коммуникативной культуре: история и современность [“You” and “уоu” addressing in russian commucative culture: history and modernity']. 
Материалы для отчетной лекции 27.7.2009. Кичкинэ. philology.by/ uploads/logo/goritskaya_crimea.doc (20.9.2015).

Grice $1985=$ Г. П. Грайс. Логика и речевое общение ['Logic and speech communication']. - Е. В. Падучева (Ed.), Новое в зарубежной лингвистике. Выпуск 16: Лингвистическая прагматика. Москва: Прогpecc.

Grigorjeva 2011 = Л. Н. Григорьева. Понятие параллельного текста и его роль в процессе перевода ['Parallel text concept and it's role in translating process']. - В. И. Шадрин (Ed.), Университетское переводоведение. Выпуск 11: Материалы XI международной научной конференции по переводоведению «Федоровские чтения» 20-23 октября 2010 г. Санкт-Петербург: Издательство Санкт-Петербургского Университета, 146-151.

Keevallik, Leelo 1998. Sinatamisest ja teietamisest koolilaste arvamuste põhjal ['The use and abuse of singular and plural address through the eyes of the Estonian schoolchildren']. - Keel ja Kirjandus 8, 541-553.

Kokšarova, Vogelberg 2009 = И. Кокшарова, К. Фогельберг. Прагматические значения обращений ты / Вы у эстонцев, русских в России и русскоязычной диаспоры Эстонии ['Pragmatic concern of adressing forms among Estonians, Russians in Russia and Russians in Estonia']. - И. П. Кюльмоя (Ed.). Humaniora: Lingua Russica. Активные процессы в русском языке диаспоры и метрополии. Труды по русской и славянской филологии. Лингвистика XII. Tapту: Tartu Ülikooli kirjastus, 45-65.

Kudrjavcev 1998 = Ю. Кудрявцев. Этикетное значение отчества ['Etiquette concern of Patronymic']. - Аспект / Aspekti 1 (58), 31-40.

Lakoff, Robin 1973. The logic of politeness: Or, minding your p's and q's. Claudia W. Corum, Thomas Cedric Smith-Stark, Ann Weiser (Eds.), Papers from the ninth regional meeting of the Chicago linguistic society. Chicago: Chicago Linguistic Society, 292-305.

LES $1990=$ Лингвистический энциклопедический словарь ['Linguistic encyclopedic dictionary']. Москва: Советская энциклопедия.

Lin, Tao 2013. The Concepts of "Politeness": A Comparative Study in Chinese and Japanese Verbal Communication. - Joanna Radwańska-Williams (Ed.), Intercultural Communication Studies (ICS) XXII: 2. University of Rhode Island, USA, 151-165.

Pajusalu, Renate 2010. Teie või sina? [“'You” or “you”?'] - Oma keel 1, 5-10. 
Pajusalu, Renate, Virve Vihman, Birute Klaas, Karl Pajusalu 2010. Eestlaste ja venelaste suhtluskäitumine: sina, teie ja keegi veel ['Politeness behavior among Estonians and Russians: formal and informal second person and the third person']. - Eesti Rakenduslingvistika Ühingu aastaraamat 6, 207-224. http://dx.doi.org/10.5128/ERYa6.13

Pajusalu, Renate 2014. Palved eesti, soome ja vene keeles: grammatika pragmaatika teenistuses ['Requests in Estonian, Finnish and Russian: Grammar and pragmatics']. - Eesti Rakenduslingvistika Ühingu aastaraamat 10, 241-257. http://dx.doi.org/10.5128/ERYa10.15

Rathmayr 2013 = Ренате Ратмайр. Русская речь и рынок. Традиции и инновации в деловом и повседневном общении ['Russian speech and market. Tradition and innovation in official and everyday communication']. Москва.

Risinzon 2010 = С. А. Рисинзон. Использование этикетных средств в деловой беседе ['Etiquette means of politeness in business talks']. - Русский язык: исторические судьбы и современность: IV международный конгресс исследователей русского языка: Труды и материалы. Москва: Издательство Московского университета, 205-206.

Sologub 2009 = О. П. Сологуб. О взаимодействии искусственного и естественного начал в сфере официально-делового общения (к вопросу об антиномическом устройстве официально-делового языка) ['On interaction of artificial and natural bases in the sphere of formal communication (on the problem of antinomic structure of formal language)']. Вестник Томского государственного университета. Филология. Выпуск № 3 (7), 49-59.

Svinina 2007 = Н. М. Свинина. Речевая вежливость в различных культурах ['Verbal politeness in different cultures']. - Вестник Новосибирского государственного университета. Серия: История, филология. Том 6, выпуск 4: Востоковедение, 87-91.

Sviridova 2010 = Е. В. Свиридова. О принципе вежливости в аргументативном дискурсе ['About Politeness principle in argumentative discourse']. - Логико-философские штудии, 167-175.

Uzerina 2004 = М. С. Узерина. Этика делового общения ['Ethics of business communication']. Ульяновск.

Veermets, Martin 2007. Ehitus- ja remondilepingud: juriidiline abi eraisikule ja firmale [Construction contracts: Legal assistance for the civilian and business person]. Tallinn: Agitaator. 
Vlasjan 2011 = Г. Р. Власян. Коммуникативная категория вежливости: проблема интерпретации ['Communicative category of Politeness: interpretation problem']. - Вестник Челябинского государственного университета. № 33 (248). Филология. Искусствоведение. Вып. 60, 36-38.

Vlast 2007 = Власть ['The Power'], № 43 (747), 5.11.2007. http://www.kommersant.ru/doc.aspx? docsid=821763 (23.09.2015).

Watts, Richard J. 2003. Politeness. Key Topics in Sociolinguistics. Cambridge: Cambridge University Press. http://dx.doi.org/10.1017/ CBO9780511615184

\section{Jelena Velman-Omelina}

Tartu Ülikooli slavistika osakond

Lossi 3, 51003 Tartu, Estonia

jelena.velman@ut.ee

\section{Valentina Štšadneva}

Tartu Ülikooli slavistika osakond

Lossi 3, 51003 Tartu, Estonia

valentina.schadneva@ut.ee 


\title{
About polite forms in official parallel texts in Estonian and Russian
}

\author{
JELENA VELMAN-OMELINA, \\ VALENTINAŠTŠADNEVA \\ University of Tartu
}

The article deals with polite forms in Estonian and Russian when addressing an unfamiliar person interested in acquisition of socially important information. The main object of analysis consists in personal pronouns in the function of polite addressing, but other accompanying forms of politeness realisation are also considered: forms of verbs-predicates, etiquette nouns-addresses, proper names.

Written business language implemented by means of the paper channel of communication served as the source of language material. Printed matter from various agencies, institutions, and companies (booklets, flyers, etc.) was considered. The study covers business texts of informative, explanatory, instructional, and (to some extent) promotional character, in parallel in Estonian and Russian. The purpose for comparing original documents in Estonian and Russian translations thereof consists in identification of the similarities and differences upon realisation of the politeness principle in primary and secondary texts.

The analysed language material indicates that both Russian and Estonian business etiquette are currently subject to innovation, for which reason the speech etiquette means turn out to be partly variative. The article systematizes the identified translation concordance options. Comparing of the original documents in Estonian and Russian translations thereof suggests that different translation approaches exist with respect to contemporary socially oriented commercial texts: incl. direct translations of the type Sina - Tbl and Teie - Bbl, as well as the translation Sina - Bbl. In secondary texts, translation of singular verb forms in Estonian using plural verb forms in Russian is also typical.

Keywords: address forms, speech etiquette, official translated text, parallel text, Estonian, Russian 